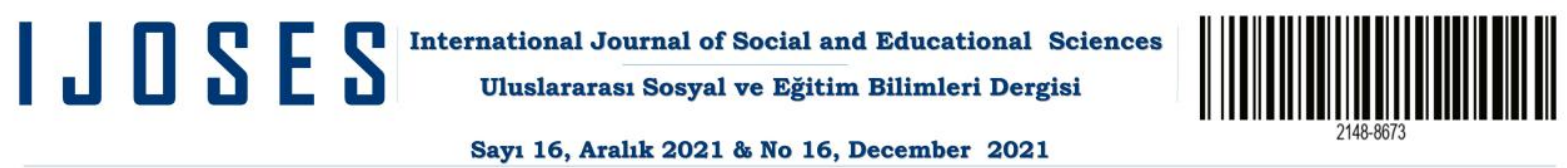

Sosyal Bilgiler Dersinde Sanal Müze Kullanımı Hakkında Öğrenci Görüşleri

Student Opinions about the Use of Virtual Museum in Social Studies Lesson

$*$

Ceylan Çınar

Öğretmen

Milli Ĕgitim Bakanlı̆̆

ceylancinar101@gmail.com

ORCID ID: 0000-0001-5918-0083

\section{Ceren Utkugün}

Dr. Öğretim Üyesi

Afyon Kocatepe Üniversitesi cerendemirdelen@hotmail.com

ORCID ID: 0000-0002-5911-9175
Ahmet Ali Gazel

Prof. Dr.

Afyon Kocatepe Üniversitesi agazel@aku.edu.tr

ORCID ID: 0000-0002-7211-6032

\section{Makale Bilgisi / Article Information}

\author{
Makale Türü / Article Type : Araştırma Makalesi \\ Geliş Tarihi / Received : 1 Kasım 2021 \\ Kabul Tarihi / Accepted : 18 Kasim 2021 \\ Yayın Tarihi / Published : 15 Aralık 2021 \\ DOI Number : 10.20860/ijoses.1017419
}

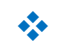

Bu çalışma, Afyon Kocatepe Üniversitesi Sosyal Bilimler Enstitüsü Sosyal Bilgiler Eğitimi Programında tamamlanmış olan "Öğrencilerin Sosyal Bilgiler Dersinde Sanal Müze Kullanımı Hakkındaki Görüşleri: İstanbul Örneği” başlıklı yüksek lisans tezinden türetilmiştir.
\end{abstract}

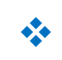

\section{Kaynak Gösterme / Citation}

Çınar, C. \& Utkugün, C. \& Gazel A. A. "Sosyal Bilgiler Dersinde Sanal Müze Kullanımı Hakkında Öğrenci Görüşleri". Uluslararast Sosyal ve Eğitim Bilimleri Dergisi, 16 (2021): 150-170. 


\title{
Sosyal Bilgiler Dersinde Sanal Müze Kullanımı Hakkında Öğrenci Görüşleri
}

\author{
Student Opinions about the Use of Virtual Museum in Social Studies Lesson
}

Ceylan Çınar \& Ceren Utkugün \& Ahmet Ali Gazel

$\ddot{O} z$

Bu araşıırma ortaokul 7. sınıf öğrencilerinin Sosyal Bilgiler dersinde sanal müze kullanımı hakkında görüşlerini belirlemek amacıyla nitel araştırma yöntemiyle fenomenoloji deseninde tasarlanmıştır. Çalışmanın katılımcıları 2020-2021 eğitim öğretim yılı bahar yarıyılında İstanbul Arnavutköy'de bir ortaokulda 7. sınıfta öğrenim görmekte olan 100 öğrenciden oluşmaktadır. Covid-19 salgını nedeniyle eğitim uzaktan devam ettiği için çalışma online yürütülmüş ve zoom uygulaması üzerinden gerçekleştirilen online derslerde sanal müzeler hakkında bilgi verilerek, örnek bir sanal müze gezisi yapılmıştır. Sonrasında öğrencilere Kurtuluş Savaşı Müzesi ve Cumhuriyet Müzesi'nin sanal gezi linkleri atılmış, yapacakları sanal müze gezisinde kullanmaları için araştırmacılar tarafından hazırlanan çalışma yaprakları verilmiştir. Sanal müze gezisi sonrasında açık uçlu sorulardan oluşan sanal müze görüş formu paylaşılarak öğrencilerin formdaki soruları yazıı olarak cevaplamaları istenmiştir. Elde edilen veriler betimsel analiz tekniği ile çözümlenmiş, veriler tablolaştıılarak frekanslarla sunulmuş, doğrudan alıntılarla desteklenmiştir. Araştırma sonunda; öğrencilerin Sosyal Bilgiler dersinde sanal müze gezileri yapılmasının öğrenmeye katkı sağlayacağını düşündükleri, sanal müze turlarının müze gezilerine bir alternatif oluşturarak zaman ve mekan kıııtlamasını ortadan kaldırdığı, ders ortamını zenginleştirerek öğrenme-öğretme sürecini eğlenceli hale getirdiği sonucuna ulaşılmıştır. Öğrenciler ders etkinliği olarak sanal müze gezisi yapmaktan hoşlanmakla birlikte; müze atmosferini hissettikleri ve sanal tura göre daha bilgilendirici, canlı ve eğlenceli bulduklarını vurgulayarak müze gezilerini sanal müze gezilerine tercih ettiklerini açıklamışlardır.

Anahtar Kelimeler: Sosyal Bilgiler Dersi, Müze, Sanal Müze, Ortaokul Öğrencisi.

\section{Abstract}

This research was designed in a phenomenology pattern with a qualitative research method in order to determine the views of secondary school 7th grade students about the use of virtual museums in the Social Studies course. The participants of the study consisted of 100 students studying in the 7th grade in a secondary school in Arnavutköy, Istanbul in the spring semester of the 2020-2021 academic year. Since the education continued remotely due to the Covid-19 epidemic, the study was carried out online and an exemplary virtual museum tour was made by giving information about virtual museums in online lessons held via the zoom application. Afterwards, the virtual tour links of the War of Independence Museum and the Republic Museum were sent to the students, and they were given worksheets prepared by the researchers to use in their virtual museum tour. After the virtual museum visit, the virtual museum opinion form consisting of open-ended questions was shared and the students were asked to answer the questions in the form in writing. The obtained data were analyzed with the descriptive analysis technique, the data were tabulated and presented with frequencies and supported by direct quotations. At the end of the research; it was concluded that the students thought that making virtual museum trips in the social studies course would contribute to learning, that virtual museum tours created an alternative to museum trips, eliminating time and space restrictions, enriching the course environment and making the learning-teaching process fun. Although students like to take a virtual museum tour as a lesson activity; they emphasized that they felt the museum atmosphere and found it more informative, lively and entertaining than the virtual tour, and stated that they preferred museum tours to virtual museum tours.

Keywords: Social Studies Course, Museum, Virtual Museum, Secondary School Student. 


\section{Extended Summary}

\section{Purpose and Significance:}

It is frequently emphasized in the literature that the use of museums in teaching activities positively affects the learning process. In this context, museums can be expressed as one of the institutions that can be used in social studies course. Considering the ease of access and use, it can be expressed that social studies education, especially with virtual museums, enables students to obtain historical gains more easily. On the basis of constructivist education, it is extremely important for students to know how virtual museums are perceived by students, which especially appeal to the field of visual intelligence and play an important role in making learning permanent by creating a rich learning environment, and to identify their deficiencies and use them in lessons. In this research, it is aimed to determine the opinions of students about virtual museums that are frequently used in Social Studies course.

\section{Methodology:}

This research was designed in a phenomenology pattern with a qualitative research method in order to determine the views of secondary school 7th grade students about the use of virtual museums in the Social Studies course. The participants of the study consisted of 100 students studying in the 7 th grade in a secondary school in Arnavutköy, Istanbul in the spring semester of the 2020-2021 academic year. The study group was formed by using the convenient sampling method, which is one of the non-random sampling types. Since the education continued remotely due to the Covid-19 epidemic, the study was carried out online and an exemplary virtual museum tour was made by giving information about virtual museums in online lessons held via the zoom application. Afterwards, the virtual tour links of the War of Independence Museum and the Republic Museum were sent to the students, and they were given worksheets prepared by the researchers to use in their virtual museum tour. After the virtual museum visit, the virtual museum opinion form consisting of open-ended questions was shared as a data collection tool and the students were asked to answer the questions in the form in writing.

The collection of opinions was provided through written forms in order to increase the number of participants and to reach the participants more easily, as the schools switched to distance education due to the Covid 19 epidemic. Before the application, it was stated that all the information of the students participating in the study would be kept confidential and they were asked not to write their names in order to be able to answer the questions sincerely. In addition, it was stated that the answers given by the students to the questions would not be used other than for the purpose of the research. The obtained data were analyzed with the descriptive analysis technique, the data were tabulated and presented with frequencies and supported by direct quotations.

\section{Results, discussion and conclusion:}

In this study; it was concluded that the students thought that making virtual museum tours in the social studies course would contribute to learning, that virtual museum tours created an alternative to museum tours, eliminating time and space restrictions, enriching the course environment and making the learning-teaching process fun. Although students like to take a virtual museum tour as a lesson activity; they emphasized that they felt the museum atmosphere and found it more informative, lively and entertaining than the virtual tour, and stated that they preferred museum tours to virtual museum tours.

The majority of the students who stated that they took a museum trip stated that they went to the museums with a school trip, and it was determined that the rate of students visiting the museum independently or with their families was very low. The fact that the study group resides in Arnavutköy, which is far from the center of Istanbul, is considered to be an obstacle for students to access museums in Istanbul. In addition, it was concluded that there is a positive relationship between the rates of making 
museum trips and the educational status of the parents, based on the fact that the educational status of the parents of the study group was illiterate, primary and secondary school graduates.

Today, when technology is the center of our lives, it has been determined that the rate of students visiting virtual museums is very low. The Covid-19 epidemic, which affected the whole world in 2020, has made distance education a part of our lives as well as face-to-face education. In addition, virtual trips have become an alternative not only for students, but also for everyone who wants to visit, as there are curfews in some periods due to the epidemic, and the closure of areas such as museums and ruins (Peker, 2020). However, it is seen that students do not use virtual museum trips much during the epidemic period. The factors affecting the rate of virtual trips can be listed as the fact that students do not have an individual phone due to their age, trouble in obtaining a device to connect to, lack of internet connection in their region, lack of infrastructure, insufficient encouragement of their parents, teachers not using virtual trip activities in classes.

The students emphasized that the virtual museum tours they made within the scope of the social studies course contributed to learning, that they had easy access to virtual museums, and that they enriched the course environment and made the learning-teaching process fun. This result shows that students have positive attitudes towards the usability of virtual museums as an educational environment in social studies courses. The students who participated in the study emphasized that virtual museums have negative aspects as well as positive aspects. It is seen that the stated negative aspects are concentrated in the statements that the tours to be made in the virtual environment do not give the psychological effect of the museums, and that they cannot create an environment of concretization, learning by doing and living.

\section{Giriş}

Geçmişten günümüze yaşanan teknolojik gelişmelerle birlikte eğitim-öğretim anlayışında da köklü değişimler görülmüştür. Öğretmenin merkezde olduğu geleneksel öğretim yöntemleri yerini öğrenci merkezli, öğrencinin yaparak-yaşayarak aktif öğrenmesine olanak sağlayan çağdaş öğretim yöntemlerine bırakmıştır. Bu durum eğitim-öğretim faaliyetlerinin sınıf ve okuldan ziyade okul dışında ve gerçek hayatla bir arada olması anlamına gelmektedir (Dinç ve Uztemur, 2017). Avcı ve Gümüş (2020)'e göre okul dışı eğitim, öğrencilerin gerçek hayatla bağlantı kurarak tecrübeyle kazandığ 1 bilgilerin kalıcı olmasını sağlamaktadır. Günümüz teknolojisinde öğrencilerin hayatı anlamlandırması, deney ve gözleme dayalı öğrenme gerçekleştirmesi noktasında okul dışı öğrenmeler daha önemli hale gelmektedir (Tuncel ve Dolambay, 2020).

Sosyal Bilgiler dersi, ilk ve ortaokul basamaklarında okutulan tarih, coğrafya, arkeoloji, antropoloji, sosyoloji gibi birçok disiplinin sentezlenmesi ile oluşmuş mihver bir derstir. Öğrencilerin geçmişi öğrenmesine olanak veren kültürel miras konularının öğretimi Sosyal Bilgiler ve Tarih dersleriyle mümkün olmaktadır (Mazman Budak, 2021). 2004 yılında yenilenen öğretim programları sonrasında, Sosyal Bilgiler Öğretim Programı ile müze ve öğrenme programı ilişkisi kurulmuştur. Sosyal bilgiler ve tarih konularının öğrencilerin zihinlerinde daha kalıcı hale gelmesine olanak sağlayan alanlar müze ve tarihi mekanlardır. Dolayısıyla müzeler ve tarihi mekanlar Sosyal Bilgiler dersinde tarih konularının öğretiminde önemli bir kaynaktır. Okul ortamında kavramanın zor ve zahmetli olduğu soyut konuların öğretiminde müzeler ve tarihi mekanlar somut öğrenme yaşantıları sunarak öğrencilerin gelişimine katkı sağlar (Seidel ve Hudson, 1999). Yapılan çalışmalarda müzelerin bir öğrenme ortamı olarak kullanıldığında öğrencilerin güdülerini arttırarak daha kalıcı öğrenmelerin gerçekleşmesini sağladığından bahsedilmektedir (Kaschak, 2014; Marcus, 2008; Tran, 2006). Müze gezileriyle ilgili yapılan lisansüstü tez çalışmalarında müze gezilerinin öğrencilerde olumlu tutum oluşmasına ve ders kazanımlarının daha kolay elde edilmesine katkı sağladığı görüşü yer almaktadır (Akyüz, 2009; Demirboğa, 2010; Demirci, 2009; Filiz, 2020; Tosun, 2009; Utku, 2008). Önder, Abac1 ve Kamaraj 
(2009) da öğretimin sadece sınıfta kitaplarla gerçekleşmeyeceği, öğrenme sürecinde farklı ortamların da kullanılması gerektiğini ve bu noktada müzelerin önemini belirtmektedir. Öğrenciler müzelerde hem toplu öğrenme ortamı bulmakta hem de kendilerini farklı bir öğrenme ortamında görerek bilgiyi hafızalarına kolayca yerleştirmektedir. Öğrenciler yapmış oldukları müze gezileri ve alan çalışmaları ile gezmiş oldukları mekanları kendi yaşam alanları ile karşılaştırma imkanı bularak mekansal algılama kapasiteleri artacak ve mekan-tarih ilişkilerini daha rahat kavrayabileceklerdir. Bu durumun doğal bir sonucu olarak da öğrenci yakından uzağa ilkesi ile olayları küresel boyutta düşünme becerisi kazanacaktır (Meydan ve Akkuş, 2014). Müzeler ve tarihi mekanlar; Sosyal Bilgiler Dersi Öğretim Programında öngörülen, aynı zamanda öğrencide geliştirilmesi hedeflenen beceri ve değerlerin kazandırılmasına olanak sağlamaktadır (Ata, 2015). Yapılan çalışmalarda müze ve tarihi mekanların öğrencilerde aktif katılım, tarihsel empati, gözlem, zaman, mekan ve kronolojiyi algılama, değişim ve sürekliliği algılama gibi sosyal bilgilere özgü becerilerin gelişmesine olumlu katk1 sağladığ 1 belirtilmektedir (Çulha, 2006; Doğan, 2020; Ilgaz ve Örten, 2015; Meydan ve Akkuş, 2014; Yeşilbursa, 2008; Yılmaz ve Şeker, 2011, Üztemur, Dinç ve Acun, 2018; Albadawi, 2020; Tserklevych, Prokopenko, Goncharova, Horbenko, Fedorenko \& Romanyuk, 2021; Aktaş, Y1lmaz ve İbrahimoğlu, 2021). Sosyal Bilgiler dersinde öğrencilerin müze ve tarihi mekanlarda somut gözlemler yaptıkları tarihi eserler; kanıt temelli argüman geliştirme, tarihsel empati, geçmiş ve günümüz arasında bağ kurarak değişimi anlama ve tarihte süreklilik gibi kavramları somut hale getirerek bu becerilerin kazanılmasına yardımcı olur (Çulha, 2006; Doğan, 2020; Yılmaz ve Şeker, 2011). Tarihi mekanların ve müzelerin Sosyal Bilgiler dersinde kullanılması, unutulmak üzere olan yapıt ve değerlerin öğrenci tarafından keşfedilirken tarihsel empati becerisi de kazanmalarını sağlamaktadır (Üztemur, Dinç ve Acun, 2018).

2008 yılında Talim Terbiye Kurulu Başkanlığı müzelerin öğrenme sürecinde aktif kullanılmasını yaygınlaştırmak ve aynı zamanda müze-okul işbirliğini geliştirmek amacıyla Sosyal Bilgiler Öğretim Programına müze ile eğitim kılavuzu eklenerek müzelerin eğitimde verimli şekilde kullanılması gerekliliği vurgulanmıştır (MEB, 2008). Öğrencide tarihsel anlama ve tarihsel düşünme becerisinin geliştirilmesi hedefiyle; sosyal bilgiler öğretiminde, müze çalışmalarına ağırlık vermeye başlanmıştır. Müze deneyimi sonunda öğrencilerin kendi tecrübelerini ve kişisel farklılıklarını göz önünde bulundurarak tarihsel duygudaşlık ve koleksiyonları eleştirel gözlemleme imkanı yakalaması amaçlanmaktadır (Aktaş, Yılmaz ve İbrahimoğlu, 2021). Son yıllarda müzede eğitim etkinlikleri kapsamında drama ve rol oynama yöntemleri etkin olarak kullanılmaya başlamıştır. Çetin (2002), Maccario Kuruoğlu (2002), Önder vd. (2009) ve Şahan (2005) yaratıcı drama ve rol oynamanın müze eğitiminde son yıllarda daha etkin kullanıldığını ifade etmektedir. Okvuran (2012) de yapılandırmacı yaklaşıma uygun olarak dramayla birlikte dokun yap gibi yaklaşımlarla öğrencilerin oyunla öğrenmesinin önemini vurgulamaktadır. Yapılan çalışmalarda müze gezilerinin eğitim ortamı olarak etkililiğinin yanı sıra olumsuz yanları da yer almaktadır. Müze gezileriyle ilgili en sık bahsedilen şikayetler; öğretim programının aksayabileceği düşüncesiyle müdürlerin izin vermek istememeleri, çok fazla emek gerektirmesi, öğretmenlerin konuyla ilgili bilgi eksikliği, zaman ve para sıkıntısı, kalabalık grupların kontrolünün zor olması ve bürokratik süreçlerin zahmetli olması şeklinde literatürde yer almaktadır (Keleş, 2003; Demirci, 2009). Bu sorunların üstesinden gelinmesi için modern müzeciliğin önemli yaklaşımları arasında da gösterilen sanal müzelerden yararlanılabileceği görüşü dile getirilebilir (Keleş, 2003; Şahan, 2005).

Günümüz dünyasının vazgeçilmez bir iletişim aracı haline gelen internet, bilgisayar aracılığıyla müzecilik faaliyetlerinin değişim ve gelişim yaşamasına sebep olmuştur (Buyurgan ve Mercin, 2005). Teknolojinin gelişim süreci içerisinde birçok müze bilgisayar ve internete göre baştan oluşturulmuştur. Bu oluşum içerisinde internet imkanı ile her an ziyaret edilebilen sanal müzeler yıllar geçtikçe yaygınlık kazanarak toplum tarafindan benimsenen bir oluşum haline gelmiştir. İnternet teknolojisinde yaşanan hızlı gelişim ve internet kullanımının yaygınlık kazanmasıyla müzecilik yeni bir merhale kazanmış, böylece sanal müze ortaya çıkmıştır (Özer, 2007). Bilişim çağının getirdiği teknolojik avantajlar 
eşliğinde müzelerde yer alan eser ve objeler dijital bir özellik kazanmıştır. Sınırsız ziyaretçinin dolaşım yapmasına olanak tanıyan sanal müzeler, küresel anlamda erişim sağlayarak uzaktan ve hayat boyu eğitimi bilimsellikle örtüşen güvenli içerikler barındırmaktadır (Yücel, 2012). Sanal müzelerin tasarlanması ile müzeler, elektronik ortamda koleksiyonlarını sergileyen ve daha fazla insana hitap eden bir konuma gelmiştir. İnternet aracılığıyla müzeleri rahat bir şekilde ziyaret edebilen kullanıcılar eserleri inceleyerek gözlem yapabilme olanağı yakalamıştır (Durmuş, 2012). Eğitim boyutunda ele alındığında sanal geziler, sosyal ve ekonomik koşulları müsait olmayan öğrencilere okulların gezi yapabilmesi açısından faydalı olabilecek firsatlardır. Okulun bulunduğu bölgede eğitim kazanımları sağlayacak gezi mekanlarının yetersizliği, velilerin ekonomik açıdan yetersiz kalması, güvenlik zafiyetlerinin bulunması çoğu zaman gözlem yönteminin sanal geziler biçiminde gerçekleştirilmesini gerektirmektedir. Dolayısıyla Sosyal Bilgiler dersine yönelik öğretim faaliyetlerinde önemli katkılar sağlaması açısından sanal gezilerden yararlanılabilir (Tuncel ve Dolanbay, 2017). Sanal müze uygulamalarıyla Sosyal Bilgiler dersi arasında sıkı bir ilişki oluştuğu söylenebilir. Teknolojik donanım ile desteklenmiş sanal müzelerin kullanımıyla öğrencilerin tarihi konuları daha anlamlı şekilde öğreneceği düşünülmektedir. Somut öğrenmeler için uygun koşulları sağlaması ve dünyanın herhangi bir yerinde bulunan bir müzenin eserlerine web site üzerinden ulaşılması yönünden sanal müzelerin önemli avantajlar sağladığ görülmektedir. Aktif öğretim metodlarını destekleyen sanal müzelerle öğrenci bilişsel ve duyuşsal anlamda daha dolu öğrenmeler gerçekleştirebilir (Aktaş, Yılmaz ve İbrahimoğlu, 2021), öğrencilerin motivasyonları arttırılarak kalıcı öğrenmeler sağlanabilir (Kayabaşı, 2005). Öğrencilerin gerçekçi durumlar ile meşgul olmalarını sağlayan sanal müzeler eğlenceli bir öğrenme ortamı sunarak kavram öğretimini kolaylaştırmaktadır (Shim, Park, Kim, Kim, Park ve Ryu, 2003). Sanal müze uygulamasına ağırlık verilmesiyle sosyal bilgiler eğitiminde zaman ve mekan kısıtlaması olmaksızın müze koleksiyonları öğrenciler tarafindan incelenebilecektir (Turan, 2015). Ata' (2010) ya göre sanal müze uygulamalarıyla sınıf içi ders işleyişi kaliteli hale getirilerek öğrencide eğitsel yönde ilerlemeler kaydedilebilecektir. Sosyal Bilgiler dersinde sanal müze gezileriyle desteklenecek öğretim etkinliklerinin oldukça yararlı olacağı (Yıldırım ve Tahiroğlu, 2012) ve sanal müzeler ile daha başarılı müze deneyimlerinin yaşandığ vurgulanmaktadır (Çolak, 2006). Aladağ, Akkaya ve Şenöz (2014), Sosyal Bilgiler derslerinde sanal müze kullanılmasını değerlendirmek üzere Aydın ilinde görev yapan ve Sosyal Bilgiler dersinde sanal müze kullanan 10 öğretmen ile görüşme yapmıştır. Araştırma sonucunda bölgeye uzaklıkları nedeniyle gezilme imkanı olmayan müzelerin öğrencilere gösterilip tanıtıldığından hareketle sanal müzelerin öğrenciler ve öğretmenler açısından önemli ve faydalı bir materyal olduğu, ancak sanal müzelerin kullanımları esnasında sıkıntılar yaşandığı tespit edilmiştir. Yıldırım ve Tahiroğlu (2012) 5. sınıf Sosyal Bilgiler dersi esnasında öğrencilerin derse karşı tutumları açısından sanal ortamda yapılan müze gezilerinin etkisini incelediği araştırma sonucunda; ders ortamında yapılan sanal gezi etkinliklerinin ilköğretim öğrencilerinin Sosyal Bilgiler dersine yönelik motivasyonları üzerinde olumlu bir etki oluşturduğu görülmüştür. Zantua (2017) 6. sınıf öğrencilerinin Sosyal Bilgiler dersinde öğrenme üzerinde sanal gerçeklik uygulamalarının etkisini araştırdığı çalışma sonucunda; sanal gerçeklik uygulamalarının öğrenmeye olumlu anlamda katkı sağladığı ve ekonomik bir çözüm sunduğu tespit edilmiştir.

Sosyal Bilgiler dersinde dijital materyal olarak kullanılan sanal müzeler öğrenme ortamlarını daha ilgi çekici hale getirmektedir. Bu öğrenme ortamlarından etkili bir şekilde faydalanmak için öğrenci deneyim ve görüşlerini göz önünde bulundurmak gerekmektedir. Bu bağlamda yapılandırmacı eğitim temelinde öğrencilerin özellikle görsel zeka alanına hitap eden, zengin bir öğrenme ortamı oluşturarak öğrenmenin kalıcı hale getirilmesinde önemli rol oynayan sanal müzelerin öğrenciler tarafından nasıl algılandığını bilmek ve eksik yönlerinin tespit edilerek derslerde kullanmasını sağlamak sanal müzelerden alınacak fayda için son derece önemlidir. Bu araştırmada Sosyal Bilgiler dersinde sıklıkla kullanılan sanal müzeler hakkında öğrenci görüşlerini belirlemek amaçlanmaktadır. Bu genel amaç dğrultusunda aşağıdaki sorulara cevap aranmıştır: 
1. 7. sınıf öğrencilerinin müze gezisi yapmanın öğrenmeye katkısı hakkında görüşleri nelerdir?

2. 7. sınıf öğrencilerinin müze gezilerinin sanal müzelerden farkı hakkında görüşleri nelerdir?

3. 7. sınıf öğrencilerinin sanal müze gezilerinin yararları ve sınırlılıkları hakkında görüşleri nelerdir?

4. 7. sınıf öğrencilerinin Sosyal Bilgiler dersinde sanal müze kullanımı hakkında görüşleri nelerdir?

5. 7.sınıf öğrencilerinin sanal müze gezisi yaparken yaşadıkları sıkıntılar hakkında görüşleri nelerdir?

6. 7. sınıf öğrencilerinin sanal müze gezilerini devam ettirme konusunda görüşleri nelerdir?

\section{Yöntem}

Araştırma deseni Sosyal Bilgiler dersinde sanal müze kullanımı hakkında öğrenci görüşlerinin değerlendirildiği bu çalışma, nitel araştırma yöntemine göre tasarlanmıştır. Nitel araştırma, "gözlem, görüşme ve dokuman analizi gibi nitel veri toplama tekniklerinin kullanıldığı, algıların ve olayların doğal ortamda gerçekçi ve bütüncül bir biçimde ortaya konmasına yönelik nitel bir sürecin izlendiği araştırma" olarak tanımlanır (Yıldırım ve Şimşek, 2018: 39). Çalışmada nitel araştırma desenlerinden fenomenolojik desen kullanılmıştır. Fenomenolojik desen kişinin bir duruma, olaya ve deneyime yönelik bakış açısını ele alan bir modeldir (Patton, 2014). Fenomenolojik desende araştırmacı; insanların kendi bakış açılarından bir olguyu nasıl anlamlandırdıklarını açıklamaya çalışır. Ayrıca bu desende kişilerin bakış açıları incelenir (Johnson ve Christensen, 2014). Bu araştırmada da ortaokul 7.sınıf öğrencilerinin bakış açılarından hareketle Sosyal Bilgiler dersinde sanal müze kullanımı hakkında görüşlerinin incelenmiştir.

\section{Çalışma grubu}

Araştırmacılardan birinin öğretmen olarak çalıştığı İstanbul Arnavutköy’de bir devlet okulunda 7. sınıfta öğrenimlerine devam etmekte olan 100 adet öğrenci araştırmanın çalışma grubunu oluşturmaktadır. Çalışma grubu, seçkisiz olmayan örnekleme türlerinden uygun örnekleme yöntemi kullanılarak oluşturmuştur. Uygun örnekleme yöntemi; zaman, para ve işgücü kaybını engellemek için seçilen grubun kolay çalışılabilir kişilerden oluşmasıdır (Büyüköztürk vd., 2008). Bu çalışmada ögrencilerin evlerinde sanal müze gezisi yapabilecekleri bir cihaz bulunması ve genel ağ bağlantısı olması durumları göz önünde bulundurularak çalışma grubu oluşturulmuştur. Çalışma grubunun özellikleri Tablo 1'de verilmiştir.

Tablo 1. Çalışma Grubuna Ait Özellikler

\begin{tabular}{llll}
\hline \multirow{2}{*}{ Cinsiyet } & & $\mathrm{f}$ & $\%$ \\
& Kadın & 55 & 55 \\
& Erkek & 45 & 45 \\
\hline \multirow{4}{*}{ Anne eğitim durumu } & Okuma yazma bilmiyor & 19 & 19 \\
& İlkokul & 52 & 52 \\
& Ortaokul & 21 & 21 \\
& Lise & 8 & 8 \\
& Yüksekokul & - & - \\
& Üniversite ve üstü & - & - \\
\hline & Okuma yazma bilmiyor & 5 & 5 \\
& İlkokul & 47 & 47 \\
\multirow{3}{*}{ Baba eğitim durumu } & Ortaokul & 37 & 37 \\
& Lise & 10 & 10 \\
& Yüksekokul & - & - \\
\hline
\end{tabular}




\begin{tabular}{llll}
\hline & Üniversite ve üstü & 1 & 1 \\
\hline Sanal müze etkinliğine & Cep telefonu & 82 & 82 \\
bağlanılan cihaz durumu & Tablet & 11 & 11 \\
& Bilgisayar & 7 & 7 \\
\hline Öğrencilerin bilgisayar ve & Çok iyi & 15 & 15 \\
genel ă̆ kullanabilmeleri & İyi & 33 & 33 \\
hakkında öz & Orta & 47 & 47 \\
değerlendirmeleri & Kötü & 5 & 5 \\
\hline Öğrencilerin müze gezisi & Müze gezisi yapmadım & 64 & 64 \\
yapma durumları & Müze gezisi yaptım & 36 & 36 \\
\hline Öğrencilerin etkinlik & Sanal müze gezisi yaptım & 32 & 32 \\
öncesi sanal müze gezisi & Sanal müze gezisi yapmadım & 68 & 68 \\
yapma durumları & & & \\
\hline
\end{tabular}

\section{Veri toplama aracı}

Veri toplama aracı olarak öğrencilerin sanal müze kullanımı hakkındaki görüşlerini belirlemek amacıyla uzman görüşü alınarak hazırlanan, açık uçlu sorulardan oluşan sanal müze görüş formu kullanılmıştır. Nitel araştırmalarda veri toplama aracı olarak mülakat dışında açık uçlu anket soruları, gözlemler ve yazılı yansıtıcı ifadeler de kullanılabilmektedir (Rands ve Gansemer-Topf, 2016). Görüş formunda yer alan soruların kapsam geçerliliğini sağlamak üzere alan uzmanından gelen dönütlerin ardından 15 olan soru sayısının 9'a indirilmesi kararlaştırılmıştır. Görüş formu çalışma grubuna uygulanmadan önce 38 öğrenci üzerinde pilot uygulaması yapılmış ve uygulama sonucuna göre forma son hali verilmiştir.

Sanal müze görüş formu iki bölümden oluşmaktadır. İlk bölümde çalışma grubunu tanımlayabilmek için; cinsiyet, anne-baba eğitim durumu, sanal müze gezisine hangi cihazdan bağlandıkları, bilgisayar ve genel ağ kullanabilme hakkındaki görüşleri, daha önce müze ve sanal müze ziyaretinde bulunup bulunmadıkları sorulmuştur. Açı uçlu 9 sorudan oluşan ikinci bölümde öğrencilerin Sosyal Bilgiler dersi kapsamında sanal müze kullanımı hakkındaki görüşlerini anlamlandırmak için ise şu sorular yöneltilmiştir. "Sosyal Bilgiler dersinde müze kullanımının konuları öğrenmenize katkı sağlayacă̆ını düşünüyor musunuz?", "Müze gezisini sanal müzeden ayıran noktalar nelerdir?", "Sanal müze gezisinin yararları nelerdir?", "Sanal müze gezisinin sinırlılıkları nelerdir?", "Sosyal Bilgiler dersinde sanal müze kullanımının konuları ögrenmenize katkı sağlayacağını düşünüyor musunuz?", "Sanal müze gezilerini yaparken ne gibi sıkıntılar yaşadınız?", "Sanal müze gezisi yapmayı sürdürecek misiniz?”.

\section{Verilerin toplanması ve analizi}

Araştırma yayın etiği kurallarına uygun olarak tamamlanmıştır. Gerçekleştirilen araştırma çerçevesinde Afyon Kocatepe Üniversitesi Bilimsel Araştırma ve Yayın Etiği Kurulu'ndan (Etik Kurul Kararı 24.05.2021 Tarih ve 2021/07 Konulu) etik izin alınmıştır. Uygulama MEB'e bağlı bir kurumda gerçekleştirildiğinden Milli Eğitim Bakanlığı'na bağlı Okul ve Kurumlarda Yapılacak Araştırma ve Araştırma Desteğine Yönelik İzin ve Uygulama Yönergesine (MEB, 2007) uygun hareket edilmiştir. Uygulamaya başlamadan önce gerekli resmi izin alınmıştır.

Araştırma verileri, 2020-2021 bahar yarıyllı içerisinde, İstanbul ilinin Arnavutköy ilçesinde bir devlet okulunda 7. sınıfta öğrenim görmekte olan ve çalışmaya katılmaya gönüllü 100 öğrenciden toplanmıştır. Covid-19 salgını nedeniyle eğitim uzaktan devam ettiği için çalışma, araştırmacılardan biri tarafından zoom uygulaması üzerinden gerçekleştirilen online Sosyal Bilgiler dersi kapsamında gerçekleştirilmiştir. Derste örnek bir sanal müze gezisi yapılarak sanal gezinin nasıl yapılacağ gösterilmiştir. Sonrasında öğrencilere Sosyal Bilgiler dersinde işlenmekte olan konuya uygun olarak belirlenen Kurtuluş Savaşı Müzesi ve Cumhuriyet Müzesi'nin sanal gezi linkleri (Kültür ve Turizm 
Bakanlığı, 2021) sanal müze gezisi yapmaları için atılmıştır. Sanal müze gezisi sonrasında ise açık uçlu sorulardan oluşan sanal müze görüş formu paylaşılarak soruları yazılı olarak cevaplamaları istenmiştir. Görüşlerin toplanması hem Covid 19 salgını nedeniyle okulların uzaktan eğitime geçmiş olması hem de katılımcı sayısını arttırmak ve katılımcılara daha kolay ulaşmak amacıyla yazılı formlar aracılığıyla sağlanmıştır. Uygulama öncesinde çalışmaya katılan öğrencilerin tüm bilgilerinin gizli tutulacağ 1 aktarılmış ve sorulara içtenlikle cevap verebilmeleri için isimlerini yazmamaları istenmiştir. Ayrıca öğrencilerin sorulara verdikleri cevapların araştırma amacı dışında kullanılmayacağı ifade edilmiştir.

Elde edilen veriler betimsel analiz ile çözümlenmiştir. Betimsel analiz, görüşme sonrası elde edilen verilerin belli bir kategoriye ayrılarak okuyucuya aktarılmasıdır. Önce eldeki veriler betimlenir, sonrasında betimlemeler açıklanır ve yorumlama işlemi ile çalışma sonuçlandırılır. Bu analiz türünde sık sık doğrudan alıntılamalara yer verilerek çalışma grubunun görüşleri ayrıntılı bir şekilde açıklanmak istenir (Yıldırım ve Şimşek, 2018). Betimsel analiz 4 aşamadan oluşmaktadır: 1. aşamada betimsel analiz için bir çerçeve oluşturulur. 2. aşamada tematik çerçeveye göre veriler işlenir. 3. aşamada bulgular tanımlanır. 4. ve son aşamada ise elde edilen bulgular yorumlanarak çalışma sonlandırılır (Altunışık, Coşkun, Bayraktaroğlu ve Yıldırım, 2010). Analizler sonucunda elde edilen veriler tablolaştırılarak frekanslarla sunulmuş, doğrudan alıntılarla desteklenmiştir. Verilerin sunumunda alıntı seçimi için çarpıcılık (farklı görüş), açıklayıcılık (temaya uygunluk), çeşitlilik ve uç örnekler ölçütleri dikkate alınmıştır (Ünver, Bümen ve Başbay, 2010). Bulguların sunumunda etik kurallar gereği katılımcı gizliliğini korumak amacıyla öğrenciler Ö1, Ö2.. şeklinde belirlenen kısaltmalar ile ifade edilmiştir.

\section{Bulgular}

Bu bölümde verilerin analizi sonucunda ulaşılan bulgulara ve doğrudan alıntılara yer verilmiştir.

\section{Sosyal Bilgiler Dersinde Müze Gezisi Yapmanın Öğrenmeye Katkısı Hakkında Öğrenci Görüşleri}

Öğrencilerin "Sosyal Bilgiler dersinde müze kullanımının konuları öğrenmenize katkı sağlayacă̆ını düşünüyor musunuz?" sorusuna verdikleri yanıtların analizi sonucunda oluşturulan tema, kod ve frekanslar Tablo 2'de gösterilmiştir.

Tablo 2. Sosyal Bilgiler Dersinde Müze Kullanımının Öğrenmeye Katkısı Hakkında Öğrenci Görüşleri

\begin{tabular}{llc}
\hline Temalar & Kodlar & f \\
\hline \multirow{3}{*}{ Katkı sağlar } & Müze gezilerinin tarih konularını öğrenmeye etkisi & 20 \\
& Müze gezilerinin dersle ilgili yeni bilgiler öğrenme üzerinde etkisi & 11 \\
& Müze gezilerinde eserleri canlı olarak görmenin öğrenmeye etkisi & 10 \\
& Müzelerde sergilenen eserlerle ders konularının paralellik & 8 \\
& göstermesi & 3 \\
\hline Kararsız & Müze gezilerinin dersi eğlenceli hale getirmesi & 2 \\
\hline Katkı sağlamaz & Müze gezilerinin öğrenmeye etkisi hakkında kararsı olmak & 1 \\
\hline
\end{tabular}

97 öğrenci Sosyal Bilgiler dersinde müze gezisi yapmanın derslerine katkı sağlayacağını ifade ederken 2 öğrenci karasız kalmış ve 1 öğrenci ise katkısı olmayacağını söylemiştir. Öğrencilerin neredeyse tamamı Sosyal Bilgiler dersinde müze gezisi yapılmasının derslerinde başarılarını olumlu yönde etkileyeceğini belirtmiştir. Sosyal Bilgiler dersinde müze kullanımının öğrenmeye katkı sağlayacağını düşünen öğrencilerin bazı görüşleri şu şekildedir: 
Ö30“.....Bu kişinin öğrenmesine bă̆ll bir şeydir bence. ... Insan müzeyi gezerken sadece orada sergilenenlere bakarsa pek bir şey ögrenemez. Fakat oradaki sergilenenlere bakarken hem baklyor hem de bilgi metnini okuyorsa bilgi sahibi olur bunun Sosyal (Bilgiler) dersiyle alakasi da şudur örneğin bir tarih müzesi gezisinde müze içinde gördüklerimizi kavrarsak Sosyal (Bilgiler) dersinde bu konularla ilgili olduğundan dolayı çok fayda sağlayacă̆ını düşünmekteyim.”

Ö40 “.....derste işlediğimiz konuları tarih müzelerinde gezdikten sonra bilgi kafamızda pekişir ve kalıcı olur."

Ö52 “..... Sosyal Bilgiler dersi için fayda sağlayacă̆ını düşünüyorum çünkü Sosyal Bilgiler dersinin bir alanı da tarih. Müze deyince benim aklıma tarihi şeyler geliyor ve tarihi görerek hissederek ögrenmenin faydalı olacă̆ını düşünüyorum."

Derste öğrendikleri bilgilerle ilgili eserleri canlı bir şekilde görmelerinin derslerine katkı sağlayacağını Ö32 "Müze gezilerini yakından görmemiz aklımızda kalıcı fikirler bırakabilir Sosyal (Bilgiler) dersi öğrendiklerimizle de pekişir." şeklinde belirtirmiş; Ö93 ise "Derslerimizi daha ĕ̆lenceli bir şekilde öğrenebiliriz." diyerek müze gezilerinin dersleri daha eğlenceli hale getireceğini ifade etmiştir.

\section{Müze Gezilerinin Sanal Müzelerden Farkı Hakkında Öğrenci Görüşleri}

Öğrencilerin “Müze gezisini sanal müzeden ayıran noktalar nelerdir?” sorusuna verdikleri yanıtların analizi sonucunda belirlenen kodlar ve frekansları Tablo 3’te gösterilmiştir.

Tablo 3. Müze Gezilerinin Sanal Müzelerden Farkı Hakkında Öğrenci Görüşleri

\begin{tabular}{lc}
\hline Kodlar & f \\
\hline Müzelerde eserlerin yakından görülmesi & 25 \\
Sanal müzelerin ulaşım/erişim kolaylı̆̆ının olması & 13 \\
Müzelerin gerçek eserlerin sergilendiği yerler olması & 11 \\
Müzelerde müze atmosferinin hissedilmesi & 11 \\
Müzelerde detaylı inceleme yapılabilmesi & 8 \\
Müze gezilerinin zaman kısıtlamasının olması & 5 \\
Müzelerde eserlere dokunulabilmesi & 5 \\
Müzelerin belirli kurallarının olması & 3 \\
Müze gezisinde fazla enerji harcanması & 3 \\
Müzelerin pandemide riskli olması & 2 \\
Müzelerin biletsiz gezilmesi & 2
\end{tabular}

Tablo 3 incelendiğinde öğrenciler müze gezilerinin sanal müzelerden fark1 olarak; müzelerde eserleri yakından gördükleri, müze atmosferini hissettikleri, müzelerde detaylı incelemeler yapabildiklerini; sanal müzelerin ise erişim kolaylığını ve Covid 19 saldınında bulaş riski olmadan gezmeye elverişli olduğunu vurgulamışlardır. Ö38 "Müzelerde sergilenen eserlere daha yakından baktı̆̆ımı için daha etkili oluyor fakat sanal müzelerde bu böyle olmuyor." diyerek müzelerde eserlerin araya bir engel girmeden yakından ve canlı olarak görülmesini sanal müzelerden ayıran önemli bir özellik olarak ifade etmiştir. Ö10 "Müze gezilerini müzelere giderek yapmak zorundayken, sanal müzede istediğimiz yerde yapabiliriz (örneğin oturduğumuz yerde). Bu bir ev veya kafe gibi çeşitli yerler olabilir. Müzelere girmek için belirli saatler varken, sanal müzelerde belirli bir saat aralı̆̆ yoktur. Kişi, istediği zaman bu müzeleri ziyaret edebilir." ve Ö94 "Müzeleri kendin gidip görürsün. Sanal Müzeler sana gelir." diyerek sanal müze gezilerinin erişim/ulaşım kolaylığını vurgulamışlardır. Ö53 ise "Mesela müze gezilerinde bazı kurallara uyarız ama sanal ortamda bu kurallara uyumuyoruz. Müze gezilerinde kendin geziyorsun görüyorsun fakat sanal müzelerde bunları yapamıyoruz." diyerek müze gezilerinde uyulmas1 gereken kurallar olduğunu belirtmiştir. Ö62 "Müzede eşyaları canlı olarak görürüz, sanal müzeler de ise internetten resmini." 
ve Ö89 “Tarihi yerinde görmek o atmosferi yaşamak ve o ani hissetmek ve görerek yaşamak sanal müzeden daha güzel." ifadeleri ile sanal müze gezilerinin dezavantajlarını belirtmişlerdir. Ö24 Covid 19 salgını nedeniyle müze gezileri daha iyi olsa da bulaş riski olduğunu "Bence müze gezilerinde her şeyi canlı olarak görebiliyoruz ama sanal olarak daha iyi çünkü covid döneminde avantajı çok yüksek..." şeklinde ifade etmiştir.

\section{Sanal Müze Gezilerinin Yararları ve Sınırlılıkları Hakkında Öğrenci Görüşleri}

“Sanal müze gezisinin yararları ve sınırlılıkları nelerdir?” sorusuna ilişkin öğrenci görüşleri analiz edilmiş, belirlenen temalar, kodlar ve frekanslar Tablo 4'te gösterilmiştir.

Tablo 4. Sanal Müzelerin Yararları ve Sınırlılıkları Hakkında Öğrenci Görüşleri

\begin{tabular}{llc}
\hline Temalar & Kodlar & f \\
\hline & Sanal turun istenilen mekandan yapılabilmesi & 34 \\
& Sanal turun istenilen zaman yapılabilmesi & 12 \\
& Sanal müze gezisinin sağlık açısından güvenilir olması & 8 \\
& Sanal müzelerin ücretsiz ve biletsiz olması & 6 \\
& Kisa sürede birçok müze gezisi yapılabilir olunması & 5 \\
& Sanal müze gezisinde yorulmadan gezilebilmesi & 3 \\
& Sanal müzeye masraf yapmadan ulaşılabilmesi & 2 \\
& Sanal müze gezisiyle zaman tasarrufu yapılması & 2 \\
& & 20 \\
& Eserleri canlı görememe & 16 \\
& Bir dezavantajı yok & 14 \\
& İnternet gerekliliği/Bağlantı sorunu oluşması & 9 \\
& Gerçek esere dokunulamaması & 9 \\
& Müze atmosferini yansitmaması & 8 \\
& Eserlerin ayrıntılı incelenememesi & 4 \\
\hline & Bilmiyorum & \\
\hline
\end{tabular}

Tablo 4'te görüldüğü üzere öğrenciler sanal müzelerin yararları ve sınırlılıkları konusunda yakın frekanslarla vurgu yapmışlardır. Öğrenciler sanal müzelerin yararları konusunda zaman ve mekan serbestliği, Covid 19 bulaş riski, ücretsiz ve masrafsız olmasına değinmişlerdir. Ö1 "Müzeler bizden uzak olduğundan gidemiyorum ama internet üzerinden her şeyi gördüm." ve Ö10 "İstediğimiz zaman, istediğimiz yerde girebiliriz. Ya da yürüme engelli bir kişi müzelere gidemese bile, sanal olarak birçok müzeyi gezebilir ve çeşitli bilgileri olduğu yerden öğrenebilir.” diyerek ulaşım kolaylığ vurgusunda bulunurken; Ö34 "Pandemi günlerinde evimizden çıkmadan daha güvenli ve kolay bir şekilde gezebiliyoruz." diyerek covid 19 salgınında bulaş riski olmadan gezebilme avantajını belirtmiştir. Ö54 "Oturduğunuz yerden bir saatin içinde 5-6 müze gezebiliriz, hem de zaman tasarrufu yapmış oluruz." ve Ö45 "İstediğimiz zaman ücretsiz şekilde gezebiliriz." ifadeleriyle sanal müzelerin zaman tasarrufu sağlaması, masrafsız olmasını ifade etmişlerdir.Öğrencilerin büyük çoğunluğu sanal müzelerin sınırlılıkları konusunda eserleri görüp inceleyip dokunamamak, müze atmosferinin olmaması, bağlantı sorunları ve internet gerekliliğini vurgulamışlarken bazı öğrenciler dezavantajının olmadığını belirtmişlerdir. Ö12 “Biraz tuhaf geldi. Çünkü canlı bir şekilde gezmekle eş değer değil" ve Ö77 "Bence sanal müze benim için yeterli değildir. Neden derseniz onları canlı canlı görmek isterim” diyerek müze atmosferine; Ö74 "İnternet olmadan sanal müzelerde gezi yapamayız." diyerek internet gerekliliğine ve Ö23 "Hiçbir şeye dokunamıyoruz, daha dikkatli bakamıyoruz" diyerek sanal müzelerde detaylı inceleme yapamıor olmalarını ifade etmişlerdir. 


\section{Sosyal Bilgiler Dersinde Sanal Müze Kullanımı Hakkında Öğrenci Görüşleri}

"Sosyal Bilgiler dersinde sanal müze kullanımının öğrenmeye katkı sağlayacağını düşünüyor musunuz?” sorusuna ilişkin öğrenci görüşlerinin analizi sonucunda belirlenen temalar, kodlar ve frekanslar Tablo 5 'te gösterilmiştir.

Tablo 5. Sosyal Bilgiler Dersinde Sanal Müze Kullanımının Öğrenmeye Katkısı Hakkında Öğrenci Görüşleri

\begin{tabular}{clc}
\hline Temalar & Kodlar & f \\
\hline \multirow{3}{*}{ Katkı sağlar } & Sanal müze gezileri ile müzelerin sınıfa taşınması & 16 \\
& Sanal müze gezileri ile tarih konularının daha iyi anlaşılması & 11 \\
& Sanal müzelerdeki eserlerle ders konularının paralellik göstermesi & 10 \\
& Sanal müze gezisinde bulunan görsellerin kalıcı öğrenme sağlaması & 8 \\
& Sanal müze gezileri ile yeni bilgiler öğrenilmesi & 4 \\
& Sanal müze gezileri ile derslerin eğlenceli hale gelmesi & 3 \\
\hline Katkı sağlamaz & & \\
\hline
\end{tabular}

Öğrenciler Sosyal Bilgiler dersinde sanal müze kullanımının öğrenmeye katkısı konusunda müzelerin sınıfa gelmesi, daha kolay ve eğlenceli öğrenme ortamı oluşturması ve kalıcı öğrenme sağlaması vurgusunda bulunmuşlardır. Sanal müze kullanımının öğrenmeye olumlu katkısı olduğunu belirten bazı öğrencilerin görüşleri şu şekildedir:

Ö16 “..... Müzelere okulda her zaman gezme imkanı yakalayamayız. Ama öğretmenimiz bizi her zaman sanal müze gezdirebilir. Bu da dersleri daha iyi anlamamıza yardımcı olur."

Ö77 “.....Güzel bir çalışma gidemediğim göremediğim yerleri öğretmenimiz sayesinde gördüm.”

Ö4 “..... Ortamı hissedemesem de sergilenen nesneler, ortamlar konuyu daha akılda kalıcı kıldı."

Ö49“.....Çünkü Sosyal Bilgiler dersinde konularımızı sanal müzeler sayesinde daha kolay ve ĕglenceli bir şekilde öğrenebiliriz."

Sanal müzelerin öğrenmeye katk1 sağlamadığını savunan Ö30 "Pek düşünmüyorum çünkü bazı insanların ilgisini çekmiyor, merak uyandırmıyor. Bu da insanların ögrenememesine yol açıyor. "diyerek bireysel öğrenme farklılıklarının öğrenme üzerindeki etkisini vurgulamıştır.

\section{Sanal Müze Gezisi Yaparken Yaşadıkları Sıkıntılar Hakkında Öğrenci Görüşleri}

"Sanal müze gezisi yaparken ne gibi sıkıntılar yaşadınız?” sorusuna ilişkin öğrenci görüşlerinin analizi sonucunda belirlenen temalar, kodlar ve frekanslar Tablo 6' da gösterilmiştir.

Tablo 6. Sanal Müze Gezisi Yaparken Yaşadıkları Sıkıntılar Hakkında Öğrenci Görüşleri

\begin{tabular}{llc}
\hline Temalar & Kodlar & f \\
\hline & Sanal turu yönlendirmede zorluk yaşanması & 20 \\
& İnternette donma ve bağlantı sorunu olması & 19 \\
Sıkıntı yaşadım & Sanal gezi uygulamasından kaynaklanan sorunlar olması & 7 \\
& Etkinlikte verilen görevlerin bulunamaması & 4 \\
\hline Sıkıntı yaşamadım & - & 44 \\
\hline
\end{tabular}

44 öğrenci sanal müze gezisi sırasında bir sıkıntı yaşamadıklarını "eğlendim, çok sevdim, güzeldi" gibi kelimelerle ifade ederken 20 öğrenci sanal müzeyi gezerken sanal turu yaparken zorluk yaşadıklarını ifade etmiş̧lerdir. Ö32 "Hiç sıkıntı yaşamadım, çok güzel ĕ̆lendim sanal müzede." diyerek sanal turda eğlendiğini belirtirken; Ö5 "Noktaların üstüne basamadı̆̆ım zaman hareket 
edemedim.” ve Ö16 “İleri, geri tuşlarına sürekli elim çarptı̆̆ için biraz sıkıntı yaşadım.” diyerek sanal turda sıkıntı yaşadıklarını belirtmişlerdir. Bazı öğrenciler ise internet ve sanal gezi uygulamasından kaynaklanan sorunlar yaşadıklarını şu şekilde ifade etmişlerdir:

Ö17 “Müze odalarını bulamadım, odaların isimleri kapı üstlerinde yazsaydı daha güzel olabilirdi ve daha kolay olurdu."

Ö49 "Sürekli siteden atıordu"

Ö89 "Donmalar oldu, tam göremedim”

Öğrencilerin Sanal Müze Gezilerini Devam Ettirme Konusundaki Görüşleri

“Sanal müze gezisi yapmayı sürdürecek misiniz?” sorusuna ilişkin öğrenci görüşlerinin analizi sonucunda belirlenen temalar, kodlar ve frekanslar Tablo 7'de gösterilmiştir.

Tablo7. Öğrencilerin Sanal Müze Gezilerini Devam Ettirme Konusundaki Görüşleri

\begin{tabular}{llc}
\hline Temalar & Kodlar & f \\
\hline & Öğretici bir aktivite olması & 16 \\
Sanal müze turunu devam & Eğlenceli vakit geçirilmesi & 13 \\
ettirmeye yönelik ifadeler & Yeni yerler keşfedilmesine olanak tanıması & 8 \\
& Müzelere gitme zorunluluğunu kaldırması & 5 \\
& Pandemi nedeniyle güvenli olması & 2 \\
& Müze gezilerine göre kolay olması & 2 \\
\hline Sanal müze gezisini devam & - & 23 \\
ettirmeme düşüncesinde olanlar & & 2 \\
\hline Kararsızlık belirten ifadeler & - &
\end{tabular}

Sanal müze gezilerine devam edeceğini belirten öğrenciler; eğlenceli ve öğretici olması, yeni yerler keşfediyor olmaları, müze gezilerine göre kolay olması ve Covid 19 bulaş riskinin olmamasını vurgulamışlardır. Ö65 "Gerçeğine gitmeyi tercih ederim ama bu tür ziyaretlere covid-19 bitene kadar devam edeceğim. Çünkü şu an müzeleri gezmeye ve görmeye hastalı el vermiyor.” ve Ö35 “....Bu sayede gidemediğim müzelere bile sanal ortamda ulaşabiliyorum ve bu sayede çok fazla bilgi sahibi oluyorum." diyerek sanal müze gezilerine devam edeceklerini ifade etmişlerdir.

Sanal müze gezilerine devam etmeyeceklerini belirten öğrenciler ise tercih etmeme, ilgi çekici bulmama, sevememe gibi nedenler ifade etmişlerdir. Ö44 ".....Gerçek müzedeki gibi keyif vermiyor.”, Ö58 “ .....Covid biterse gerçek hayatta gideceğim.” ve Ö18 “.....Canlı canlı gidip görmek daha güzelken neden sanal gezi yapayım ki. Canlı canlı görmek o hissi yaşamak istiyorum. O yüzden sanal müze gezini sürdürmeyeceğim." ifadeleri sanal müze gezilerine devam etmeme açıklamalarına örnek olarak gösterilebilir.

\section{Sonuç, Tartışma ve Öneriler}

Öğrencilerin Sosyal Bilgiler dersinde sanal müze kullanımı hakkında görüşlerinin belirlenmesi amacıyla nitel araştırma yönteminde tasarlanan bu araştırma İstanbul' da bir devlet ortaokulunun 7. sınıfında öğrenimlerine devam etmekte olan 100 öğrenci ile birlikte yürütülmüştür. Bu araştırmada; öğrencilerin Sosyal Bilgiler dersinde sanal müze gezileri yapılmasının öğrenmeye katkı sağlayacağını düşündükleri, sanal müze turlarının müze gezilerine bir alternatif oluşturarak zaman ve mekan kısıtlamasını ortadan kaldırdığı, ders ortamını zenginleştirerek öğrenme-öğretme sürecini eğlenceli hale getirdiği sonucuna ulaşılmıştır. Öğrenciler ders etkinliği olarak sanal müze gezisi yapmaktan hoşlanmakla birlikte; müze atmosferini hissettikleri ve sanal müze gezisine göre daha bilgilendirici, canlı ve eğlenceli bulduklarını vurgulayarak müze gezilerini sanal müze gezilerine tercih ettiklerini açıklamışlardır. 
Müze gezisi yaptıklarını belirten öğrencilerden büyük çoğunluğu müzelere okul gezisi ile gittiklerini belirtmişler, öğrencilerin bağımsız ya da ailelileriyle müze gezisi yapma oranlarının az olduğu görülmüştür. Çalışma grubunun İstanbul ilinin merkeze uzak konumda bulunan Arnavutköy ilçesinde ikamet ediyor olmaları öğrencilerin İstanbul'daki müzelere erişimlerinin önünde bir engel olduğu düşünülmektedir. Ayrıca çalışma grubunun anne-baba eğitim durumlarının okuma yazma bilmeyen, ilkokul ve ortaokul mezunu yoğunlukta olmasından hareketle müze gezisi yapma oranları ile anne-baba eğitim durumları arasında pozitif bir ilişki olduğu sonucuna ulaşılmıştır. Kısa (2012) müze kullanımına ilişkin öğretmen ve öğrenci görüşlerini içeren araştırmasında benzer bir sonuca ulaşmış; öğrencilerin büyük bir bölümü öğretmen rehberliğinde ve okul gezileri ile müze gezilerine katılmış olduğunu belirtmiştir. Öztürk Kömleksiz ve Gökmenoğlu (2020) KKTC'deki Güzelyurt Doğa ve Arkeoloji Müzesi'ne yürüme mesafesinde bulunan iki ilkokulda öğretmen ve öğrencilerle görüşmeler yaptıkları araştma sonucunda; müzenin okula yürüme mesafesinde olmasına ragmen derslik dış1 eğitim ortamı olarak kullanılmadığı, öğretmenlerin müze eğitimine yönelik bazı destkelere gereksinim duydukları ve okulun yakınıdaki bu müzeden haberdar olmayan ögrenciler olduğunu belirtmişlerdir. Öztürk Kömleksiz ve Gökmenoğlu'na (2020) göre; müze görevlileri ve öğretmenin "Sessiz ol!", "Hiç bir şeye dokunma!" uyarılarına maruz kalan bir çocuğun müzede verimli zaman geçirmesi ve müze gezilerini sevmesi mümkün olmayacaktır. Müzeler çocukların ilgisini çekebilecek şekilde düzenlenmeli ve müzelerde çocuklara özel ilgi gösterilmelidir. Genelde müze gezilerine öğretmenlerinin zoraki yönlendirmesiyle katılan öğrenciler; müzeler ilgilerini çekmezse dikkat etmez, müzede anlatılanları da dinlemez ve dikkatleri çabuk dağılabilir. Bu nedenle müzedeki nesneler hakkında çocuklara uzun bilgiler verilmemeli ve müzeler çocukların birden çok duyusuna hitap edebilecek şekilde düzenlenmelidir (Shabbar, 2001). Müze eğitimi çocukları nesneleri görmeleri ve dokunabilmelerine imkan sağlamanın yanı sıra oyun, drama, yarışma gibi öğrencilere eğlenirken öğrenebilecekleri zengin öğrenme ortamları oluşturulmalıdır (Canl1, 2016).

Teknolojinin hayatımızın merkezi olduğu günümüzde öğrencilerin sanal müze gezisi yapma oranlarının çok düşük olduğu tespit edilmiştir. 2020 yılında tüm dünyayı etkisine alan Covid-19 salgını yüz yüze eğitimin yanı sıra uzaktan eğitimi de hayatımızın bir parçası haline getirmiştir. Ayrıca salgın nedeniyle bazı dönemlerde sokağa çıkma kısıtlamalarının olması, müze ve ören yeri gibi alanların ziyarete kapatılması sadece öğrenciler için değil gezmek isteyen herkes için sanal geziler bir alternatif olmuştur (Peker, 2020). Fakat salgın dönemi içinde öğrencilerin sanal müze gezilerini çok kullanmadıkları görülmektedir. Öğrencilerin yaşları itibariyle bireysel telefonlarının bulunmaması, bağlanılacak cihaz temininde oluşan sıkıntı, bulundukları bölgede internet bağlantısının çekmemesi, altyapı eksiklikleri, anne-babalarının öğrencileri teşvikte yetersiz kalması, öğretmenlerin derslerde sanal gezi etkinliklerini kullanmıyor olması sanal gezi yapılma oranını etkileyen etmenler arasında sayılabilir. Demir (2009) sınıf öğretmenlerinin derslerde gerçek ve sanal gezilerini kullanmadıklarını; Karakaya (2015) öğrencilerin Sosyal Bilgiler dersinde gerçek müzelerden ve sanal müzelerden yararlanma oranlarının düşük olduğunu belirtmişlerdir. Benzer şekilde, Egüz ve Kesten'in (2012) araştırmasına katılan öğretmenlerin büyük bölümü sanal müzeler hakkında bilgi sahibi olmamaları, teknolojik imkanlarının eksikliği, müfredat yetiştirme kaygısı gibi gerekçeler öne sürerek sınıfta sanal müze gezisi yapmadıkları, ancak yapmalarının yararlı olabileceğini ifade etmişlerdir.

Öğrenciler ders etkinliği olarak sanal müze gezisi yapmaktan hoşlandıklarını belirtmekle birlikte; sanal müze gezisine göre daha bilgilendirici ve eğlenceli buldukları vurgusuyla müze gezilerini tercih ettiklerini açıklamışlardır. Öğrenciler müze gezilerini sanal müze gezilerine tercih etmelerini; müze atmosferini hissedememek, detaylı inceleme yapamamak, müze gezilerini sanal tura göre daha eğlenceli bulmak şeklinde açıklamışlardır. Çalışmaya katılan öğrenciler Sosyal Bilgiler dersi etkinliği olarak sanal müze gezisi yapmaktan hoşlandıklarını ifade etmekle birlikte müze atmosferini hissetme, fotoğraftan/ekrandan değil de canlı canlı görme, dokunma, daha bilgilendirici ve eğlenceli olması gibi nedenlerle müze gezilerini sevdiklerini açıklamışlardır. Sosyal bilgilerin temel amacının 
bireyi topluma hazırlayacak duruma getirmek olmasından hareketle gerçek kaynakların sınıfın dışında olduğu bir konu alanında öğreneni sadece sınıf içinde tutmak, bu amacın gerçekleşmesinde yeterli olmayacaktır (Altın ve Demirtaş, 2009). Öğretim etkinliklerinde müzelerden yararlanmanın öğrenci tutum ve kazanımlarına sağladığı olumlu katkılar alanyazında yapılmış çalışmalarda ortaya konulmuştur. Çalışkan, Önal ve Yazıcı (2016) 'nın öğretim etkinliklerinde sanal müze kullanımı hakkında sosyal bilgiler öğretmen adayları ile yürütmüş olduğu çalışmada öğretmen adayları müzelerin Sosyal Bilgiler dersinde öğretim ortamı olarak kullanılmasının öğrencilerde kalıc1 öğrenme gerçekleşmesine yardımcı olacağı, aktif ve eğlenceli bir öğrenme ortamı sağlayacağ1, somutlaştırma, tarihi konuların sevdirilmesi ve empati kurulması gibi nedenlerden ötürü müze eğitimine olumlu baktıklarını belirtmişlerdir. Koca ve Daşdemir (2018) Sosyal Bilgiler öğretiminde sanal tur uygulamalarının öğrenci başarısına etkisini incelemek üzere deneysel yöntemde bir araştırma yapmıştır. Deney ve kontrol grupları oluşturarak kontrol grubundaki öğrencilere Türk Tarihinde Yolculuk ünitesi geleneksel yöntem ve tekniklerle işlenmiş, deney grubu öğrencilerine ise sanal tur uygulamalarıyla işlenmiştir. Uygulamalar sonucunda deney grubu öğrencilerinin ön test ve son test sonuçları arasında olumlu yönde bir anlamlılık bulunmuştur, sanal tur uygulamalarının öğrencilerinin akademik başarılarını arttırdığı sonucuna ulaşılmıştır. Kaschak (2014) müzelerin öğrencilerin tarihsel olayları ve vatandaşlık konularını anlamalarını kolaylaştıracağını, Selanik Ay ve Kurtdede Fidan (2014) öğrenilenlerin kalıcılığına ve bazı kavramların somutlaştırılmasına katkı sağladığını, Şahan (2005) sınıf ortamında sağlanamayan ya da ortaya çıkartılamayan birçok yetenek ve becerinin müzelerde kazanılabileceğini, Yılmaz ve Şeker (2011) müze gezilerinin bilgi, görsellik ve genel kültür açısından çok yararlı olduğu, öğrencilerin tarihsel düşünme becerilerinin gelişimi ile tarih, coğrafya ve genel kültür alanında gelişimlerine yardım ettiğini, Şentürk, Koca ve Gazel (2020) öğrencilerin tarih bilincini arttırdığını ve öğrencilerde tarihi eserleri koruma bilinci geliştirdiğini, Çulha (2006) tarihi mekanlarda öğrenirken olumlu tutuma sahip oldukları, empati duygusu geliştirerek bilgilerini yapılandırdıkları, akranları ile sosyal etkileşim içerisine girerek zevk aldıkları bir öğrenme süreci yaşadıklarını ifade etmişlerdir. Bu ve benzer çalışmaların sonuçlarından da anlaşılacağı üzere müze kullanımının Sosyal Bilgiler dersinin öğretiminde öğrencilere birçok açıdan büyük kazanımlar sağlayacağı ve öğrenme sürecine önemli katkılar sunacağ göz ardı edilemez bir gerçeklik olarak karşımıza çıkmaktadır.

Öğrenciler Sosyal Bilgiler dersi kapsamında yapmış oldukları sanal müze gezilerinin öğrenmeye katkısı olduğu, sanal müzelere ulaşım kolaylığına sahip olduğu, ders ortamını zenginleştirerek öğrenme-öğretme sürecini eğlenceli hale getirdiğini vurgulamışlardır. Elde edilen bu sonuç, öğrencilerin Sosyal Bilgiler derslerinde sanal müzelerin eğitim ortamı olarak kullanılabilirliğine yönelik olumlu tutumlar içerisinde olduklarını göstermektedir. Yıldırım ve Tahiroğlu'nun (2012) da belirttiği gibi sanal müzeler müze eğitiminde müzelerin yerini almasa da dersin içinde istenilen anda konuyla ilgili müzeye bağlanılıp gösterilmesiyle öğrencilerin ders kazanımlarını elde etmelerinde yararlanılabilecek bir ortam olarak değerlendirilebilir. Turgut (2015), Sosyal Bilgiler dersinde yapılan sanal müze gezi etkinlilerinin kazanımları aktarmada katkısı olduğu, öğrencilerin sanal gezi sırasında çok eğlendikleri, etkinliklerin derse hareket getirdiği ve öğrencilerin kendilerini müze gezisinde hissettikleri sonucuna ulaşmıştır. Şahin (2019) sanal müze uygulamalarında ortaokul ögrencilerinin olumlu duygular yaşadığ kullanımının sınıf ortamına katkı sağladığı sonucuna ulaşmıştır. Durmuş (2012), Sosyal Bilgiler dersinde uyguladıkları sanal müze gezilerinin öğrencilerin hoşuna gittiği, tekrar sanal müze gezisi yapmak istedikleri, diğer dersler için de benzer ortamların oluşturulmasını istedikleri ve bu tür ortamların başarılarını olumlu yönde etkileyeceğinini düşündüklerini tespit etmiştir. Ustaoğlu (2012) geleneksel yöntemle ders yapılan kontrol grubu öğrencilerinde merak duygusu oluşmazken, sanal müze uygulaması ile ders yapılan deney grubu öğrencilerinde merak duygusu uyandırdığı ve bunun da derse ilgiyi arttırdığı ve başarının arttığını belirtmiştir. Peker (2020) Sosyal Bilgiler öğretmen adayları ile yaptığı çalışmada; öğretmen adaylarının sanal müze kullanımını önemsedikleri, sanal 
müze kullanımının eğitim ve öğrenci üzerinde kalıcı ve olumlu etkisi olacağını düşündüklerini saptamıştır. Uslu (2008), Demirboğa (2010), Ermiş (2010), Egüz ve Kesten (2012) ile Yıldırım ve Tahiroğlu (2012) tarafından gerçekleştirilen çalışmalarda da derslerde sanal müzelerin kullanılmasının öğrenciler tarafından olumlu karşılandığı, bu tür etkinliklerin sevildiği ve öğrencilerin konuya ilişkin kazanımları daha kolay elde ettikleri, kalıcı bilişsel kazanımlara ulaşıldığı bulgusuna ulaşıldığı görülmektedir. Engelli, engelli olmayan ve derece sınıfı -başarılı sınıfolmak üzere üç farklı öğrenci grubuyla çalışan Okolo, Englert, Bouck, Heutsche ve Wang (2011), tarih öğretiminde sanal müzelerin tüm öğrencilerin öğrenmesine katkı sağladığı hatta engelli öğrencilerin anahtar kavramları öğrenmede en az derece sınıfı kadar başarılı olduğu sonucuna ulaşmışlardır. Glosset (2007) sanal müzelerin; sanal ortamda eserleri tekrar inceleme, eserin orjinalini görme isteği ve mrak uyandırarak gerçek mekana sahip müze ziyaretlerinin artmasına neden olduğunu vurgulamıştır.

Çalışmaya katılan öğrenciler sanal müzelerin yararları yanında sınırlılıklarının da bulunduğunu vurgulamışlardır. Belirtilen sınırlılıklar sanal ortamda yapılacak gezintilerin müzelerin verdiği psikolojik etkiyi vermediği, somutlaştırma, yaparak yaşayarak öğrenme ortamı oluşturamayacağı ifadelerinde yoğunlaştığı görülmektedir. Benzer bir sonuç Çalışkan, Önal ve Yazıcı'nın (2016) öğretmen adaylarıyla yapmış olduğu çalışmada da yer almaktadır. Çeşitli yararlarına karşın objeye dokunamama ve koridorlarda yürüyememeye bağlı olarak gerçek müze deneyimi yaşatmaması, sanal müzelere yönelik getirilen en belirgin eleştirilerden biridir (Barlas Bozkuş, 2014). Katz ve Halpern (2015) de sanal müze ziyaretçilerinde bilişsel gelişim sağlanmasının bu ortamda ziyaretçide gerçeklik duygusu yaşatılmasına bağlı olduğunu, üç boyutlu turların müze ziyaretçileri üzerinde daha etkili olduğunu vurgulamaktadır. Viralingam ve Ramaiah (2008) da hareketli ve etkileşimli ara yüzlerin web üzerindeki müze sergileri için daha uygun olduğunu ifade etmiştir. Çalışkan, Önal ve Yazıcı (2016) sanal müze ziyaretlerinden beklenen yararın elde edilmesi için, öğretim amaçlı tasarlanacak sanal müze ortamları için eğitim teknologları ve öğretim tasarımcılarından yardım alınarak başarılı bir sosyal etkileşim alanı oluşturacak ve öğrenenlerde sosyal burdalık hissettirecek üç boyutlu tasarımlar geliştirilmesi gerektiğini belirtmektedir. Ayrıca Çıldır ve Karadeniz (2014) 'in işaret ettiği gibi müzelerdeki eğitim birimlerinin sanal müzeyi kullanarak koleksiyonlarını temel alan oyun, bulmaca, video ve animasyonları içeren paket eğitim programları geliştirmesi ve okullara sunması, sanal müzelerin eğitim amaçlı kullanılmasını yaygınlaştıracaktır.

Araştırmadan elde edilen sonuçlara göre şu öneriler yapılmıştır:

- Öğrencilerin müze ve sanal müze gezisi yapma oranlarının düşük olmasından hareketle; akıllı tahtalar, okulların bilgisayar odaları ya da öğretmenlerin bireysel bilgisayarları ile sanal müze gezileri yaptırılarak derslerde aktif olarak kullanılması sağlanabilir.

- Öğrencilerin ders etkinlikleri dışında sanal müze turlarını değil de müze gezisini tercih etmelerinden hareketle ders etkinliği olarak özellikle yakın çevrede bulunan müzelere gezi yapılabilir ya da aileleriyle birlikte gezebilecekleri müzeler konusunda yönlendirmeler yapılabilir.

- Öğretim programlarındaki kazanımları desteklemek üzere öğrencilere sanal müze etkinlikleri ile ilgili ödev ya da boş zaman değerlendirici aktiviteler verilebilir, aileleriyle ya da arkadaşlarıyla gezebilecekleri sanal müze etkinlikleri tasarlanabilir.

- Çevirim içi ortamların eğitim öğretim sürecinde kullanılabilirliğini arttırmak üzere öğretmen adaylarından başlayarak lisans düzeyinde eğitimler verilebilir, müze ve sanal müze eğitimine yönelik derslerde uygulamalı eğitimler yapılarak farkındalıkları artırılabilir. Görevde bulunan öğretmenlere ise bu konuda hizmet içi eğitimler verilebilir. 


\section{Kaynakça}

Aktaş, V., Y1lmaz, A. ve İbrahimoğlu Z. (2021). Sosyal bilgiler öğretmenlerinin sanal müze kullanımına yönelik tutumları. Trakya Eğitim Dergisi, 11(3), 1294-1313.

Akyüz, G. (2009). Sanayi müzelerinin tarih ögretiminde kullanım durumu: Rahmi M. Koç müzesi örneği. (Yayımlanmamış yüksek lisans tezi). Marmara Üniversitesi Eğitim Bilimleri Enstitüsü, İstanbul.

Aladağ, E., Akkaya, D. ve Şensöz, G. (2014). Sosyal bilgiler dersinde sanal müze kullanımının öğretmen görüşlerine göre değerlendirilmesi. Trakya Üniversitesi Sosyal Bilimler Dergisi, 16(2), 199-217.

Albadawi, B. I. (2021). The Virtual Museum VM as a Tool for Learning Science in Informal Environment. Education in the Knowledge Society, 22, 1-14. https://doi.org/10.14201/eks.23984

Altın, B. N. ve Demirtaş, S. (2009). Sosyal Bilgiler dersinde sınıf dışı eğitim etkinlikleri. M. Safran (Ed.), Sosyal bilgiler öğretimi (s.508-539) içinde. Pegem Akademi Yayınları.

Altunışık, R., Coşkun, R., Bayraktaroğlu, S. ve Yıldırım, E. (2010). Sosyal Bilimlerde Araştırma Yöntemleri SPSS Uygulamalı. (6. Bask1). Sakarya: Sakarya Yayınc1lık.

Ata, B. (2010). Sosyal bilgiler eğitiminde müzelerin önemi. Turan, R. ve Ulusoy, K. (Editörler). Sosyal Bilgilerin Temelleri (s. 191-205). Ankara: Maya Akademi.

Ata, B. (2015). Okul dışı sosyal bilgiler öğretiminde müzeler. Şimşek, A. ve Kaymakçı, S. (Edt.). Okul dışı sosyal bilgiler öğretimi (s. 171-188). Pegem Akademi.

Avcı, G. ve Gümüş, N. (2020). Sınıf dışı eğitime dayalı etkinliklerle işlenen sosyal bilgiler dersine yönelik ilkokul 4. sınıf öğrenci tutumlarının incelenmesi. Batı Anadolu Ĕ̈itim Bilimleri Dergisi, 11(1), 89-106.

Barlas Bozkuş, Ş. (2014). Kültür ve sanat iletişimi çerçevesinde Türkiye'de sanal müzelerin gelişimi. The Journal of Academic Social Science Studies, 26, 329-344.

Buyurgan, S. ve Mercin, L. (2005). Görsel sanatlar eğitiminde müze eğitimi ve uygulamaları. (1. Bask1). Ankara: Görsel Sanatlar Eğitimi Derneği Yayınları, 2005.

Canl1, K. (2016). Illkokul 4. sınıf Görsel Sanatlar dersinde sanal müze uuygulamasına ilişkin ögretmen, ögrenci ve veli görüşleri. (Yayımlanmamış yüksek lisans tezi), Necmettin Erbakan Üniversitesi Eğitim Bilimleri Enstitüsü, Konya.

Çalışkan, E., Önal, N. ve Yazıcı, K. (2016). Öğretim etkinliklerinde sanal müzelerin kullanımına ilişkin sosyal bilgiler öğretmen adayları ne düşünüyor?. Turkish Studies, 11(3), 689-706.

Çetin, Y. (2002). Çağdaş eğitimde müze eğitiminin rolü ve önemi. Güzel Sanatlar Enstitüsü Dergisi, 8, 57-61.

Çıldır, Z. ve Karadeniz, C. (2014). Museum, education and visual culture practices: Museums in Turkey. American Journal of Educational Research, 2(7), 543-551.

Çolak, C. (2006). Sanal müzeler. İnet-tr'06- XI. Türkiye'de Internet Konferansı Bildirileri (21-23 Aralı 2006), 291-296, TOBB Ekonomi ve Teknoloji Üniversitesi: Ankara.

Çulha, B. (2006). Tarihsel mekânlarda keşfederek öğrenme yoluyla sosyal bilgiler ögrretimine yönelik ögrenci görüşleri. (Yayınlanmamış yüksek lisans tezi). Dokuz Eylül Üniversitesi Eğitim Bilimleri Enstitüsü, İzmir.

Demir, M. K. (2009). Sınıf öğretmenlerinin gözlem gezilerine yönelik tutum ve görüşlerinin incelenmesi. Kastamonu Ĕ̈itim Dergisi, 17(2), 467-478. 
Demirboğa, E. (2010). Sanal müze ziyaretlerinin öğrencilerin bilişsel ve duyuşsal kazanımları üzerindeki etkileri. (Yayınlanmamış yüksek lisans tezi). Gazi Üniversitesi Eğitim Bilimleri Enstitüsü, Ankara.

Demirci, M. T. (2009). Kültürel ögelerin öğretiminde müze gezilerinin önemi. (Yayınlanmamış yüksek lisans tezi). Selçuk Üniversitesi Sosyal Bilimler Enstitüsü, Konya.

Dinç, E. ve Üztemur, S. (2017). Türkiye'de sosyal bilgiler ve tarih eğitiminde müzelerin ve tarihi mekânlardan yararlanmaya yönelik araştırmaların içerik analizi. Milli Eğitim, 214, 61-84.

Doğan, Y. (2020). Müze ve çocuk: Kavramlar, ilkeler, uygulamalar. Öztürk Demirbaş, Ç., Yakar, H., Çelikkaya, T.ve Yıldırım, T. (Edt.). Yeni program ve ders içeriklerine göre sosyal bilgiler öğretimi II (s.107-146). Pegem Akademi.

Durmuş, A. (2012). Sanal Bilim ve Teknoloji Müzesinde eğitsel arayüz ajanı kullanımının öğrencilerin ilgi ve başarılarına etkisi. (Yayınlanmamış doktora tezi), Gazi Üniversitesi, Eğitim Bilimleri Enstitüsü, Ankara.

Egüz, Ş., ve Kesten, A. (2012). Sosyal bilgiler dersinde müze ile eğitimin öğretmen ve öğrenci görüşlerine göre değerlendirilmesi: Samsun ili örneği. İnönü Üniversitesi Eğitim Fakültesi Dergisi, 13(1), 81-103.

Ermiş, B. (2010). İlkögrretim 6.sınıf ögrrencilerinin görsel sanatlar dersinde "üç boyutlu sanal müze ziyareti” etkinliğine ilişkin görüşleri. (Yayınlanmamış yüksek lisans tezi). Gazi Üniversitesi/Eğitim Bilimleri Enstitüsü, Ankara.

Filiz, N. (2010). Sosyal bilgiler ögretiminde müze kullanımı. (Yayınlanmamış yüksek lisans tezi). Marmara Üniversitesi Eğitim Bilimleri Enstitüsü, İstanbul.

Glosset, N. Ş. (2007). Sanal mimarlık müzesi: sanal müzecilik. İçinde, Z. Önen, G. Tunç, ve M. Yılmaz (Ed.), Geçmişten Geleceğe Türkiye’de Müzecilik I Sempozyumu (s. 229-232). Ankara: Vekam.

Ilgaz, S. ve Örten, H. (2015). Sosyal bilgiler eğitiminde tarihi ve sanatsal mekânlara dayalı öğrenme ortamları. Koçoğlu, E. ve Sever, R. (Edt.). Sosyal bilgiler öğretiminde mekânsal öğrenme ortamları (s.285-308). Pegem Akademi.

Johnson, B. ve Christensen, L. (2014). Ĕgitim Araştırmaları Nicel, Nitel ve Karma Yaklaşımlar. Ankara: Eğiten Kitap.

Karakaya, İ. (2015). Ortaokul öğrencilerinin sosyal bilgiler dersinde müze alışkanlıkları (Giresun ili örneği). (Yayınlanmamış yüksek lisans tezi), Giresun Üniversitesi Sosyal Bilimler Enstitüsü, Giresun.

Kaschak, J. C. (2014). Museum visits in social studies: The role of a methods course. Social Studies Research and Practice, 9(1), 107-118.

Katz, J. E., \& Halpern, D. (2015). Can virtual museums motivate students? Toward a constructivist learning approach. Journal of Science Education and Technology, 24(6), 776-788.

Kayabaşı, Y. (2005). Sanal gerçeklik ve eğitim amaçlı kullanılması. The Turkish Online Journal of Educational Technology, 4(3), 151-158.

Kısa, Y. (2012). Sosyal bilgiler öğretiminde müze kullanımına ilişkin öğretmen ve öğrenci görüşleri. (Yayınlanmamış yüksek lisans tezi). Afyon Kocatepe Üniversitesi Sosyal Bilimler Enstitüsü, Afyonkarahisar. 
Keleş, V. (2003). Modern müzecilik ve Türk müzeciliği. Atatürk Üniversitesi Sosyal Bilimler Enstitüsü Dergisi, 2(1-2), 1-17.

Koca, N. ve Daşdemir, İ. (2018). Sosyal bilgiler öğretiminde sanal tur uygulamaları. Turkish Studies, 13(27), 1007-1016.

Kültür ve Turizm Bakanlığı, (2021). https://sanalmuze.gov.tr/ (Erişim Tarihi: 08.05. 2021).

Maccario Kuruoğlu, N. (2002). Müzelerin eğitim ortamı olarak kullanımı. Uludağ Üniversitesi Eğitim Fakültesi Dergisi, 15(1), 275-285.

Marcus, A. S. (2008). Rethinking museums' adult education for K-12 teachers. Journal of Museum Education, 33(1), 55-78.

Mazman Budak, F. (2021). Sosyal bilgiler dersi okul dışı öğrenme ortamları. Aktepe, V., Gündüz, M., Kurtdede Fidan, N. ve Yalçınkaya, E. (Edt.). Kuramdan uygulamaya sosyal bilgiler öğretimi. (s.324-344). Pegem Akademi.

MEB (2005). İlköğretim Sosyal Bilgiler Dersi Öğretim Programı ve Kılavuzu (4-5-6-7. Sinıflar). Talim ve Terbiye Kurulu Başkanlığı. Devlet Kitapları Müdürlüğü Basım Evi. Ankara.

MEB. (2007). Milli Ĕgitim Bakanlı̆̆ına Băglı Okul ve Kurumlarda Yapılacak Araşstırma ve Araştırma Desteğine Yönelik İzin ve Uygulama Yönergesi. http://mevzuat.meb.gov.tr/html/2594_1.html.

MEB, (2008). Illköğretim 1-8. sinıflar Türkçe, matematik, sosyal bilgiler, hayat bilgisi ile fen ve teknoloji dersi öğretim programlarında müze ile eğitim. Talim ve Terbiye Kurulu Başkanlığı. Devlet Kitapları Müdürlüğü Basımevi.

Meydan A. ve Akkuş, A. (2014). Sosyal bilgiler öğretiminde müze gezilerinin, tarihi ve kültürel değerlerin kazandırılmasındaki önemi. Marmara Coğrafya Dergisi, (29), 402-422.

Okolo, C. M., Englert, C. S., Bouck, E. C., Heutsche, A., \& Wang, H. (2011). The virtual history museum: Learning U.S. history in diverse eighth grade classrooms. Remedial and Special Education, 32(5), 417-428.

Okvuran, A. (2012). Müzede dramının bir öğretim yöntemi olarak Türkiye'de gelişimi. Eğitim ve Bilim, 37(166), 170-180.

Önder, A., Abacı, O., ve Kamaraj, I. (2009). "Müzelerin eğitim amaçlı kullanımı projesi”: İstanbul Arkeoloji Müzesi’ndeki Marmara örneklemi. Pamukkale Üniversitesi Eğitim Fakültesi Dergisi, 25, 103-117.

Özer, D. N. (2007). Sanal ortamda müzecilik. (Yayınlanmamış yüksek lisans tezi), İstanbul Üniversitesi Sosyal Bilimler Enstitüsü, İstanbul.

Öztürk Kömleksiz, F. ve Gokmenoglu, T. (2020). Müze eğitim kitapçı̆̆ı hazırlama sürecinde bir durum saptama çalışması: KKTC Örneği. Milli Eğitim Dergisi, 49(228), 365-385. DOI: 10.37669/milliegitim.714409

Patton, (2014). M. Q, Nitel araştırma ve değerlendirme yöntemleri, Ankara: Pegem Akademi.

Peker, N. (2020). Sosyal bilgiler dersinde sanal müze kullanımı ve sosyal bilgiler öğretmen adaylarının sanal müze kullanımına yönelik tutumları: Aksaray Müzesi örneği. V. Uluslararası Aksaray Seтроzуuти Bildiri Kitabı, 3-4 Kasım 2020 içinde, (s. 20-31), Aksaray: Aksaray Üniversitesi.

Rands, M. Gansemer-Topf, A. M., (2016). Phenomenography: a methodological approach for assessment in student affairs. Education Publications. 45, 1-22. 
Seidel, S. ve Hudson, K. (1999). Müze eğitimi ve kültürel kimlik. Bahri Ata (Çev.). (Yay. Haz. Bekir Onur). Ankara: Ankara Üniversitesi Sosyal Bilimler Enstitüsü Müze Eğitimi Anabilim Dalı Yayınları. No: 1.

Selanik Ay, T. ve Kurtdede Fidan, N. (2014). Öğretmen adaylarının sosyal bilgiler dersinde müzelerden yararlanmaya ilişkin görüşleri. Elektronik Sosyal Bilimler Dergisi, 13(48), 69-89.

Shabbar, N. (2001). Çocuklar için müze eğitimi. İçinde, B. Madran (Ed.), Kent, Toplum, Müze, Deneyimler-Katkılar (s. 68-73). İstanbul: Türkiye Ekonomik ve Toplumsal Tarih Vakfi.

Shim, K.-C., Park, J.-S., Kim, H.-S., Kim, J.-H., Park, Y.-C., \& Ryu, H. I. (2003). Application of virtual realityntechnology in biology education. Journal of Biological Education, 37(2), 71-74.

Şahan, M. (2005). Müze ve eğitim. Türk Eğitim Bilimleri Dergisi, 3(4), 487-501.

Şahin, K. (2019). Sosyal bilgiler dersi öğretiminde sanal müze kullanımına ilişkin öğrenci tutumlarının belirlenmesi. International Congresses on Education 19-22 Temmuz 2019 içinde, (s. 381-388), Sakarya: Sakarya Üniversitesi.

Şentürk, M, Koca M. K., Gazel A. A.(2020). Sosyal bilgiler öğretmenleri ve 7. sınıf öğrencilerinin müze kullanımına ilişkin görüşleri: Manisa ili örneği. Uluslararası Sosyal ve Eğitim Bilimleri Dergisi, 7 (13), 119-133. DOI:10.20860/ijoses.740246

Tosun, O. S. (2009). Müze incelemelerinin ilköğretim okullarındaki görsel sanatlar eğitimine katkısı (Bolu ili örneği). (Yayınlanmamış yüksek lisans tezi). Dokuz Eylül Üniversitesi Eğitim Bilimleri Enstitüsü, İzmir.

Tran, L. U. (2006). Teaching science in museums: The pedagogy and goals of museum educators. Science Education, 91(2), 278-297.

Tuncel, G. ve Dolanbay, H. (2020). Sınıf dış1 öğretim teknikleriyle sosyal bilgiler öğretimi. Sever, R., Aydın, M. ve Koçoğlu, E. (Edt.). Alternatif yaklaşımlarla sosyal bilgiler eğitimi (s. 341-397). Pegem Akademi.

Turan, İ. (2015). Okul Dışı Sosyal Bilgiler Öğretiminde Sanal Müze ve Turlar. Şimşek, A. ve Kaymakçı, S. Okul Dışı Sosyal Bilgiler Ö̆gretimi içinde (ss.189-203), Ankara: Pegem A Yayıncılık.

Turgut, G. (2015). Sosyal Bilgiler Dersinde Bir Eğitim Aracı Olarak Sanal Müzelerden Yararlanma. Yayımlanmamış Yüksek Lisans Tezi. Adnan Menderes Üniversitesi Sosyal Bilimler Enstitüsü, Aydin.

Tserklevych, V., Prokopenko, O., Goncharova, O., Horbenko, I., Fedorenko, O. \& Romanyuk, Y. (2021). Virtual Museum Space as the Innovative Tool for the Student Research Practice. International Journal of Emerging Technologies in Learning (iJET), 16(14), 213-231.

Uslu, Ö. (2008). Illköğretim ikinci kademesinde görsel sanatlar derslerinde müze ile eğitiminin etkileşimli (interaktif) ortamda gerçekleştirilmesi. Yayınlanmamış doktora tezi. Gazi Üniversitesi Eğitim Bilimleri Enstitüsü, Ankara.

Ustaoğlu, A. (2012). Illköğretim 7. sinıf sosyal bilgiler dersi Türk tarihinde yolculuk ünitesinde sanal müzelerin kullanımının öğrenci başarısına etkisi. (Yayınlanmamış yüksek lisans tezi), Gazi Üniversitesi Eğitim Bilimleri Enstitüsü, Ankara.

Utku, Ç. (2008). İlkögrretim 5.sinıf düzeyi sanat eğitiminde, müze eğitiminin öğrencilerin tutumlarına etkisi. (Yayınlanmamış yüksek lisans tezi). Gazi Üniversitesi Eğitim Bilimleri Enstitüsü, Ankara. 
Ünver, G., Bümen, N. T. ve Başbay, M. (2010). Ortaöğretim alan öğretmenliği tezsiz yüksek lisans derslerine öğretim elemanı bakış1: Ege Üniversitesi örneği. Ĕ̆itim ve Bilim Dergisi, 155(35), 6377.

Üztemur, S., Dinç, E. ve Acun, İ. (2018). Müzeler ve tarihi mekânlarda uygulanan etkinlikler aracılığıyla öğrencilerin sosyal bilgilere özgü becerilerinin geliştirilmesi. Mehmet Akif Ersoy Üniversitesi Eğitim Fakültesi Dergisi, 46, 294-324.

Viralingam, N., \& Ramaiah, C. K. (2008) Comparative study of HTML and animated user interfaces of an online exhibition. Journal of Library and Information Technology, 28(4), 43-54.

Yeşilbursa, C. C. (2008). Sosyal bilgiler öğretiminde tarihi yerlerin kullanımı. Türklük Bilimi Araştırmaları, 23, 209-222.

Yıldırım, T. ve Tahiroğlu, M. (2012). Sanal ortamda gerçekleştirilen müze gezilerinin ilköğretim öğrencilerinin sosyal bilgiler dersine yönelik tutumlarına etkisi. Elektronik Sosyal Bilimler Dergisi, 11(39), 104-114.

Y1lmaz, K. ve Şeker. M. (2011). İlköğretim öğrencilerinin müze gezilerine ve müzelerin sosyal bilgiler öğretiminde kullanılmasına ilişkin görüşmelerin incelenmesi. Ístanbul Aydın Üniversitesi Dergisi, 9, 21-39.

Yıldırım, A. ve Şimşek, H. (2018). Sosyal bilimlerde nitel araştırma yöntemleri. Ankara: Seçkin Yayıncilik.

Yücel, D. (2012). Yeni Medya Sanatı ve Yeni Müze. İstanbul Kültür Üniversitesi.

Zantua, L. S. O. (2017). Utilization of virtual reality content in grade 6 social studies using affordable virtual reality technology. Asia Pacific Journal of Multidisciplinary Research, 5(2), 1-10. 